\title{
ADAPTATION TO POSTURAL CHANGE IN PSYCHIATRIC PATIENTS
}

\author{
BY \\ A. G. MEZEY and P. H. MELVILLE \\ From the Institute of Psychiatry, Maudsley Hospital, London, S.E.5
}

Starting with Bornstein (1908), a large number of investigations have dealt with basal metabolic rates in different forms of mental illness. The literature has been reviewed by Wuth (1928) and Altschule (1953), and the findings were either negative or of doubtful validity. The influence of emotional fluctuation, at the time when the investigation was carried out, had generally not been considered. Dunbar (1954) stated that "this material is essentially inconclusive owing to the fact that most workers establish a statistical correlation with certain disease groups instead of correlating metabolic rates with the emotional state of the subject".

It is widely held (e.g., Hoskins, 1941; Bartels, 1949) that emotionally disturbed subjects tend to have a raised basal metabolism, but there is no clearcut evidence in support of this belief. Crile (1922) in animals and Deutsch (1925) in human subjects have reported a decreased oxygen consumption after distressing experiences; Segal, Binswanger, and Strouse (1928) could find no alteration of metabolism (provided the subjects had a normal thyroid function) whilst Schou (1937) and Finesinger (1939) have described a frequent small increase.

Greving (1935 and 1941) reported that schizophrenic patients, after strenous effort, show a prolonged increase of oxygen consumption and a high lactate content in the blood. Similar findings were demonstrated in young soldiers with neurocirculatory asthenia by Jones and Scarisbrick (1946) and Cohen, Johnson, Consolazio, and White (1946). In these papers the emotional state of the subjects at the time of their investigation was not fully described and the metabolic findings were not related to it.

The following inquiry was designed to investigate the influence of emotion on the metabolic rate in different postures.

The concept of metabolic rate, useful as it is from a clinical point of view, does not allow sufficient insight into the functional adaptation involved in postural change. We therefore examined separately the respiratory factors. The literature on respiratory physiology in emotion and psychological illness has been reviewed by Finesinger (1939) and by Clausen (1951). Only findings directly relevant to our observations will be discussed here.

\section{Experimental Procedure and Methods}

Thirty-two patients and 10 control subjects were tested. The patients were consecutive admissions to the Professorial Unit at the Maudsley Hospital, except a few who were untestable or had a physical disease of a type known to influence metabolic rates. No more than mild nocturnal sedation (amylobarbitone sodium or pentobarbitone, $200 \mathrm{mg}$.) was administered at the time and they were not receiving physical treatment. Their diagnoses were varied (Table I). The nature of the examination was explained to every subject the day before the test, but they had no preliminary trial and retests are not included in this series. Ten healthy volunteer subjects formed the control group.

Testing took place in the morning in a quiet ward sideroom, in which the temperature was maintained between $19^{\circ}$ and $21^{\circ} \mathrm{C}$., about four hours after a light meal. The mask was fitted and the subject lay on a couch for half-an-hour or until the pulse and ventilation volumes, used as a criteria of stability, became relatively constant. At this stage, two consecutive estimates, lasting 10 minutes each, were made in the lying position and the lower of these was used as the metabolic rate when lying. The patient was then asked to sit up (on an ordinary wooden chair adjoining the couch) for five minutes, following which a 10-minute measurement was made in this position. The patient then stood in a comfortable position and after a further five minutes, a final 10-minute measurement was taken while standing.

The emotional state of the patients was assessed on a four-point scale $(0=$ nil; $1=$ mild; $2=$ marked; $3=$ severe abnormality). Two independent ratings in respect of eight symptoms (depression, euphoria, apathy, anxiety, motor retardation, motor excitement, pressure of talk, and mutism) were made, one immediately before testing by the psychiatrist clinically responsible for the case and not associated with this investigation, the other during test procedure by the experimenter (A.G.M.). In the first rating the prevalent state of the subject was evaluated by someone well acquainted with his psychiatric history and his pattern of emotional responses. The experimenter's rating was mainly based on direct observation of the patient's behaviour during the test; 
TABLE I

EXPERIMENTAL DATA

\begin{tabular}{|c|c|c|c|c|c|c|c|c|c|c|}
\hline \multirow[t]{2}{*}{$\begin{array}{c}\text { Subject } \\
\text { No. }\end{array}$} & \multirow[t]{2}{*}{ Age } & \multirow[t]{2}{*}{ Sex } & \multirow[t]{2}{*}{$\begin{array}{c}\text { Weight } \\
\text { (kg.) }\end{array}$} & \multirow[t]{2}{*}{$\begin{array}{l}\text { Height } \\
\text { (cm.) }\end{array}$} & \multicolumn{3}{|c|}{$\begin{array}{c}\text { Energy Expenditure } \\
\text { (Cal./sq.m./hour) } \\
\% \text { of Robertson and Reid Mean }\end{array}$} & \multirow{2}{*}{$\begin{array}{c}\text { Psychological } \\
\text { Rating }\end{array}$} & \multirow{2}{*}{$\underset{\text { (lying) }}{\text { Log B.S.R. }}$} & \multirow[t]{2}{*}{ Diagnosis } \\
\hline & & & & & Lying & Sitting & $\overline{\text { Standing }}$ & & & \\
\hline $\begin{array}{c}\text { Patients } \\
1 \\
2 \\
3 \\
4 \\
5 \\
6 \\
7 \\
8 \\
9 \\
10 \\
11 \\
12 \\
13 \\
14 \\
15 \\
16 \\
17 \\
18 \\
19 \\
20 \\
21 \\
22 \\
23 \\
24 \\
25 \\
26 \\
27 \\
28 \\
29 \\
30 \\
31 \\
32\end{array}$ & $\begin{array}{l}20 \\
22 \\
24 \\
24 \\
24 \\
25 \\
27 \\
28 \\
29 \\
30 \\
31 \\
32 \\
34 \\
35 \\
36 \\
36 \\
37 \\
38 \\
38 \\
38 \\
38 \\
43 \\
46 \\
52 \\
53 \\
53 \\
55 \\
55 \\
55 \\
57 \\
58 \\
69\end{array}$ & 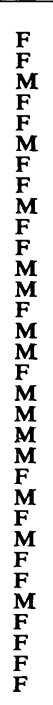 & $\begin{array}{l}55 \\
55 \\
56 \\
54 \\
45 \\
69 \\
48 \\
45 \\
59 \\
67 \\
59 \\
69 \\
78 \\
58 \\
75 \\
63 \\
40 \\
70 \\
62 \\
82 \\
62 \\
54 \\
74 \\
43 \\
69 \\
60 \\
56 \\
70 \\
39 \\
67 \\
46 \\
51\end{array}$ & $\begin{array}{l}163 \\
163 \\
165 \\
155 \\
154 \\
182 \\
157 \\
152 \\
167 \\
165 \\
157 \\
173 \\
167 \\
158 \\
171 \\
175 \\
163 \\
178 \\
165 \\
178 \\
178 \\
160 \\
174 \\
157 \\
180 \\
151 \\
147 \\
178 \\
159 \\
168 \\
156 \\
149\end{array}$ & $\begin{array}{r}82 \\
82 \\
76 \\
119 \\
110 \\
66 \\
96 \\
123 \\
84 \\
106 \\
99 \\
103 \\
121 \\
100 \\
70 \\
86 \\
89 \\
102 \\
120 \\
67 \\
101 \\
110 \\
91 \\
124 \\
88 \\
91 \\
126 \\
86 \\
98 \\
90 \\
107 \\
97\end{array}$ & $\begin{array}{r}106 \\
117 \\
108 \\
90 \\
108 \\
132 \\
89 \\
112 \\
88 \\
151 \\
110 \\
86 \\
101 \\
101 \\
125 \\
179 \\
79 \\
113 \\
144 \\
112 \\
137 \\
105 \\
101 \\
102 \\
99 \\
114 \\
97 \\
121 \\
102\end{array}$ & $\begin{array}{r}111 \\
95 \\
126 \\
82 \\
104 \\
180 \\
157 \\
122 \\
128 \\
129 \\
121 \\
87 \\
83 \\
91 \\
119 \\
168 \\
90 \\
131 \\
151 \\
148 \\
133 \\
148 \\
94 \\
92 \\
137 \\
108 \\
87 \\
82 \\
144\end{array}$ & 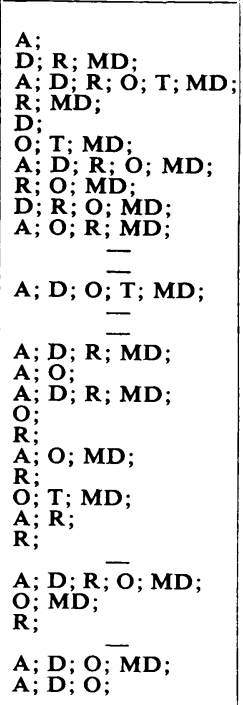 & \begin{tabular}{|l}
$0 . \overline{0000}$ \\
1.0791 \\
1.5563 \\
1.0792 \\
1.0791 \\
0.9031 \\
$1 . \overline{5797}$ \\
0.9031 \\
0.0000 \\
1.3979 \\
0.3010 \\
1.0413 \\
0.0000 \\
0.0000 \\
1.3424 \\
1.2041 \\
1.2552 \\
1.1139 \\
1.9637 \\
1.1760 \\
0.8451 \\
0.7781 \\
1.6434 \\
1.6720 \\
1.2787 \\
0.6989 \\
1.6901 \\
1.4771
\end{tabular} & $\begin{array}{l}\text { Immature personality } \\
\text { Depression } \\
\text { Mental deficiency } \\
\text { Puerperal depression } \\
\text { Depression } \\
\text { Paranoid schizophrenia } \\
\text { Depression } \\
\text { Schizo-affective disorder } \\
\text { Schizo-affective disorder } \\
\text { Depression } \\
\text { Depression } \\
\text { Hysteria } \\
\text { Schizo-affective disorder } \\
\text { Schizophrenia } \\
\text { Depression } \\
\text { Depression } \\
\text { Anxiety state } \\
\text { Depression } \\
\text { Alcoholism } \\
\text { Alcoholism } \\
\text { Schizo-affective disorder } \\
\text { Depression } \\
\text { Personality disorder } \\
\text { Anxiety state } \\
\text { Depression } \\
\text { Cerebral arteriosclerosis } \\
\text { Agitated depression } \\
\text { Huntingdon's chorea } \\
\text { Hysteria } \\
\text { Depression } \\
\text { Agitated depression } \\
\text { Depression }\end{array}$ \\
\hline $\begin{array}{l}\text { Means } \\
\text { (Patients) }\end{array}$ & $37 \cdot 9$ & & & & $97 \cdot 2$ & $111 \cdot 3$ & $117 \cdot 5$ & - & 1.067 & \\
\hline $\begin{array}{c}\text { Controls } \\
1 \\
2 \\
3 \\
4 \\
5 \\
6 \\
7 \\
8 \\
9 \\
10\end{array}$ & $\begin{array}{l}22 \\
26 \\
30 \\
30 \\
32 \\
35 \\
36 \\
37 \\
44 \\
45\end{array}$ & $\begin{array}{l}\mathbf{F} \\
\mathbf{F} \\
\mathbf{M} \\
\mathbf{M} \\
\mathbf{F} \\
\mathbf{M} \\
\mathbf{M} \\
\mathbf{M} \\
\mathbf{F} \\
\mathbf{F}\end{array}$ & $\begin{array}{l}63 \\
58 \\
70 \\
74 \\
57 \\
78 \\
64 \\
63 \\
68 \\
43\end{array}$ & $\begin{array}{l}171 \\
170 \\
187 \\
173 \\
168 \\
165 \\
171 \\
171 \\
171 \\
164\end{array}$ & $\begin{array}{r}86 \\
107 \\
114 \\
97 \\
79 \\
97 \\
114 \\
96 \\
109 \\
85\end{array}$ & $\begin{array}{r}76 \\
125 \\
125 \\
106 \\
85 \\
102 \\
134 \\
101 \\
132 \\
104\end{array}$ & $\begin{array}{r}101 \\
138 \\
124 \\
119 \\
88 \\
126 \\
146 \\
106 \\
170 \\
111\end{array}$ & $\begin{array}{l}= \\
= \\
= \\
= \\
=\end{array}$ & $\begin{array}{l}2.332 \\
0.845 \\
1.591 \\
1.977 \\
2.110 \\
1.799 \\
1.556 \\
1.113 \\
1.033 \\
2.283\end{array}$ & \\
\hline $\begin{array}{l}\text { Means } \\
\text { (Controls) }\end{array}$ & & & & & 98.4 & $109 \cdot 0$ & $122 \cdot 9$ & - & 1.663 & \\
\hline
\end{tabular}

$\mathbf{A}=$ Anxious $; \quad \mathbf{D}=$ depressed $; \quad \mathbf{R}=$ retarded $; \quad \mathbf{O}=$ overactive; $\mathbf{T}=$ over-talkative; $\mathbf{M D}=$ more disturbed

verbal communication, restricted as it was by the technique adopted, influenced it only little. The ratings of the two observers agreed closely in respect of the majority of the symptoms, especially anxiety. The two ratings were averaged and the mean was taken as the score for each symptom. The emotional state of the patients ranged from practically normal (Subject 20, an alcoholic admitted for treatment of long-standing addiction) to very severe delusional fear (Subject 13, suffering from schizo-affective disorder). Only the experimenter's rating was available for Subject 11; this patient was therefore included in the whole patient group but not in any of its subdivisions according to individual symptoms. The control subjects, all personally known to the authors, were similarly rated for their behaviour during the test; their total score never exceeded 2.

For each symptom (provided numbers were sufficient for statistical treatment) the patients were divided into two groups: one similar to the control in that the given symptom was either not present or only to a minimal degree (score 1, or less), and a second group where the abnormality was marked (score 1, 5, or above). For motor retardation, however, as all the control subjects scored 0 , any patient with a positive score was put in the second group. The patients were also divided into "more disturbed" and "less disturbed", according to whether their mean total score was 4 or more or below this figure.

The integrating motor pneumotachograph developed by Wolff (1958) was used to measure respiratory volume and to collect air samples. A face mask, of the type described for use with the apparatus, was employed. It was sealed, if necessary, with plastic adhesive tape to prevent leakage. Provided the diaphragm was kept in the vertical plane, the instrument gave consistently reliable readings. Analyses of air samples for oxygen 
and carbon dioxide were made with the Scholander technique (1947), which gave readings between 20.87 and $20.91 \%$ for the concentration of oxygen in the atmospheric air. The metabolic rates were expressed as percentages of the Robertson and Reid (1952) expected mean.

Respiratory rate was recorded with a moving coil pen recorder connected to the integrating unit of the pneumotachograph and the mean respiratory rate calculated for each 10-minute period measured. Tidal air was calculated from the ratio of minute respiratory volume to respiration rate. The pulse rate was taken at the wrist for a full minute in the middle of each period.

The measurements recorded in the three groups of subjects in the lying position were compared, and then the increment (or decrement) on changing to the sitting and then to the standing position. This is essentially the procedure used in the Leistungs-Pulsindex test of exercise tolerance (Müller, 1950). Only measurements complete for the three positions of lying, sitting, and standing were thus compared. For this reason, of the original 32 patients, four had to be discarded.
The galvanic skin resistance was measured with a valvevoltmeter type of apparatus as described by Venables (1955), modified to give direct readings in kilo-ohms. The electrodes were applied to the palmar surface of the hands with electrode jelly interposed.

Blood samples for serum protein iodine estimation were taken immediately after testing, and the haemoglobin and erythrocyte sedimentation rate measured, to exclude subclinical physical disorders which might influence metabolic rate. The results were in every instance within normal limits.

\section{Results}

The distribution of metabolic rates (Tables I and II), in all three positions and for both groups of subjects (Melville and Mezey, 1959) is within the normal range as observed in the series of similar size of Booyens and McCance (1957).

In the lying position, the average difference in calorie cost between patients and controls is only

TABLE II

MEAN SCORES FOR RESPIRATORY FACTORS AND PULSE RATE OF ANXIOUS AND NON-ANXIOUS PSYCHIATRIC PATIENTS AND OF NORMAL CONTROLS, LYING, SITTING, AND STANDING

\begin{tabular}{|c|c|c|c|c|}
\hline & & $\begin{array}{c}\text { Anxious } \\
\text { Patients }\end{array}$ & $\begin{array}{l}\text { Non-anxious } \\
\text { Patients }\end{array}$ & $\begin{array}{c}\text { Normal } \\
\text { Controls }\end{array}$ \\
\hline $\begin{array}{l}\text { No. of subjects } \\
\text { Mean age } \\
\text { Sex }\end{array}$ & & $\begin{array}{c}11 \\
39 \cdot 4 \\
5 M^{+}+6 F\end{array}$ & $\begin{array}{c}17 \\
39 \cdot 3 \\
9 M^{+}+8 F\end{array}$ & $\begin{array}{c}10 \\
33 \cdot 7 \\
5 M^{+}+5 F\end{array}$ \\
\hline $\begin{array}{l}\text { Mean metabolic rate (Cal./sq.m./hour) } \\
\text { Mean ventilation rate (1./hour) } \\
\text { Mean respiration rate (breaths/minute) } \\
\text { Mean tidal air (ml.) } \\
\text { Mean \% oxygen in expired air } \\
\text { Mean \% carbon dioxide in expired air } \\
\text { Mean respiratory quotient } \\
\text { Mean pulse rate (beats/minute) }\end{array}$ & $\begin{array}{l}\text { Lying } \\
\text { Sitting } \\
\text { Standing } \\
\text { Lying } \\
\text { Sitting } \\
\text { Standing } \\
\text { Lying } \\
\text { Sitting } \\
\text { Standing } \\
\text { Lying } \\
\text { Sitting } \\
\text { Standing } \\
\text { Lying } \\
\text { Sitting } \\
\text { Standing } \\
\text { Lying } \\
\text { Sitting } \\
\text { Standing } \\
\text { Lying } \\
\text { Sitting } \\
\text { Standing } \\
\text { Lying } \\
\text { Sitting } \\
\text { Standing }\end{array}$ & $\begin{array}{c}102 \cdot 2 \\
116 \cdot 1 \\
109 \cdot 3 \\
288 \cdot 0 \\
327 \cdot 0 \\
353 \cdot 1 \\
13 \cdot 78 \\
14 \cdot 22 \\
5 \cdot 73 \\
373 \\
372 \cdot 2 \\
385 \cdot 1 \\
17 \cdot 07 \\
16 \cdot 97 \\
17 \cdot 49 \\
3 \cdot 32 \\
3 \cdot 31 \\
3 \cdot 03 \\
0.86 \\
0 \cdot 85 \\
0 \cdot 87 \\
69 \cdot 1 \\
77 \cdot 8 \\
88 \cdot 2\end{array}$ & $\begin{array}{c}91 \cdot 8 \\
108 \cdot 2 \\
122 \cdot 3 \\
283 \cdot 1 \\
352 \cdot 5 \\
416.4 \\
13 \cdot 51 \\
15 \cdot 52 \\
16 \cdot 32 \\
361 \\
397 \cdot 6 \\
433 \cdot 1 \\
17 \cdot 06 \\
17 \cdot 26 \\
17 \cdot 36 \\
3.13 \\
3.03 \\
2.94 \\
0.81 \\
0.83 \\
0.83 \\
65 \cdot 1 \\
71 \cdot 0 \\
85 \cdot 16\end{array}$ & $\begin{array}{c}98 \cdot 4 \\
109.0 \\
122.9 \\
300 \cdot 6 \\
335 \cdot 5 \\
387.5 \\
13.22 \\
15.06 \\
15 \cdot 70 \\
406 \\
387 \cdot 1 \\
440 \cdot 1 \\
16.81 \\
16.95 \\
17.04 \\
3.34 \\
3.20 \\
3 \cdot 12 \\
0.81 \\
0.80 \\
0.80 \\
70 \cdot 4 \\
75.4 \\
84.8\end{array}$ \\
\hline
\end{tabular}

TABLE III

METABOLIC RATE (Cal./sq.m./hour) OF PSYCHIATRIC PATIENTS IN LYING POSITION COMPARED WITH NORMAL CONTROLS

\begin{tabular}{|c|c|c|c|c|c|}
\hline Group & $\mathbf{n}$ & $\begin{array}{c}\text { Mean Difference in } \\
\text { Metabolic Rate } \\
\text { in Lying Position } \\
\text { between Patients and Normal } \\
\text { Controls }(n=10)\end{array}$ & S.E. & & $\mathbf{P}<$ \\
\hline $\begin{array}{l}\text { All patients } \\
\text { Anxious patients } \\
\text { Depressed patients } \\
\text { Retarded patients } \\
\text { Overactive patients } \\
\text { "More disturbed" patients }\end{array}$ & $\begin{array}{l}32 \\
13 \\
11 \\
15 \\
15 \\
16\end{array}$ & $\begin{array}{r}-1 \cdot 2 \\
2.6 \\
0.4 \\
1.4 \\
0.8 \\
-0.2\end{array}$ & $\begin{array}{l}5 \cdot 68 \\
6 \cdot 31 \\
6 \cdot 33 \\
6 \cdot 52 \\
6 \cdot 74 \\
6 \cdot 45\end{array}$ & $\begin{array}{l}0.21 \\
0.41 \\
0.06 \\
0.21 \\
0 \cdot 13 \\
0.03\end{array}$ & $\begin{array}{l}0.9 \\
0 \cdot 7 \\
1.0 \\
0 \cdot 9 \\
0 \cdot 9 \\
1 \cdot 0\end{array}$ \\
\hline
\end{tabular}


TABLE IV

MEAN INCREMENT/DECREMENT IN METABOLIC RATE (Cal./sq.m./hour) IN NORMAL CONTROLS, ANXIOUS, AND NON. ANXIOUS PSYCHIATRIC PATIENTS AFTER CHANGE OF POSITION FROM LYING TO SITTING AND FROM SITTING TO STANDING

\begin{tabular}{|c|c|c|c|c|c|}
\hline Group & $\mathbf{n}$ & $\begin{array}{l}\text { Mean Increment/ } \\
\text { Decrement in } \\
\text { Metabolic Rate }\end{array}$ & S.E. & $t$ & $\mathbf{P}<$ \\
\hline $\begin{array}{l}\text { After Change of Position from Lying to Sitting } \\
\text { Normal controls } \\
\text { All patients } \\
\text { Anxious patients } \\
\text { Non-anxious patients }\end{array}$ & $\begin{array}{l}10 \\
28 \\
11 \\
16\end{array}$ & $\begin{array}{l}10 \cdot 6 \\
14 \cdot 6 \\
13 \cdot 9 \\
16 \cdot 3\end{array}$ & $\begin{array}{l}3 \cdot 12 \\
4 \cdot 38 \\
4 \cdot 86 \\
3 \cdot 89\end{array}$ & $\begin{array}{l}3 \cdot 39 \\
3 \cdot 22 \\
2 \cdot 84 \\
4 \cdot 20\end{array}$ & $\begin{array}{l}0.01 * \\
0.01 * \\
0.02 * \\
0.001^{*}\end{array}$ \\
\hline $\begin{array}{l}\text { After Change of Position from Sitting to Standing } \\
\text { Normal controls } \\
\text { All patients } \\
\text { Anxious patients } \\
\text { Non-anxious patients }\end{array}$ & $\begin{array}{l}10 \\
28 \\
11 \\
16\end{array}$ & $\begin{array}{r}13 \cdot 8 \\
6 \cdot 3 \\
-6 \cdot 8 \\
15 \cdot 0\end{array}$ & $\begin{array}{l}3 \cdot 81 \\
4 \cdot 64 \\
6 \cdot 51 \\
6 \cdot 05\end{array}$ & $\begin{array}{l}3.62 \\
1.35 \\
1.04 \\
2.47\end{array}$ & $\begin{array}{l}0.01^{*} \\
0.2 \\
0.4 \\
0.05^{*}\end{array}$ \\
\hline
\end{tabular}

*Statistically significant.

TABLE V

INCREMENT/DECREMENT IN METABOLIC RATE (Cal./sq.m./hour) OF PSYCHIATRIC PATIENTS ON STANDING UP COMPARED WITH OWN GROUP OF NORMAL CONTROLS AND ANOTHER SERIES OF NORMALS

\begin{tabular}{|c|c|c|c|c|c|c|c|c|c|c|}
\hline \multirow[b]{2}{*}{ Group } & \multicolumn{5}{|c|}{ Normal Controls $(n=10)$} & \multicolumn{5}{|c|}{ Series of Booyens and McCance $(1957)(n=35)$} \\
\hline & $\mathrm{n}$ & $\begin{array}{l}\text { Mean Difference } \\
\text { in Increment/ } \\
\text { Decrement of } \\
\text { Metabolic Rate } \\
\text { on Standing }\end{array}$ & S.E. & $\mathbf{t}$ & $\mathbf{P}<$ & $\mathbf{n}$ & $\begin{array}{l}\text { Mean Difference } \\
\text { in Increment/ } \\
\text { Decrement of } \\
\text { Metabolic Rate } \\
\text { on Standing }\end{array}$ & S.E. & $\mathbf{t}$ & $\mathbf{P}<$ \\
\hline $\begin{array}{l}\text { All patients } \\
\text { Anxious patients } \\
\text { Depressed patients } \\
\text { Retarded patients } \\
\text { Overactive patients } \\
\text { "More disturbed" patients }\end{array}$ & $\begin{array}{l}28 \\
11 \\
11 \\
13 \\
13 \\
14\end{array}$ & $\begin{array}{l}-8 \cdot 15 \\
-20.72 \\
-14.8 \\
=8 \cdot 1 \\
=4.3 \\
-7 \cdot 19\end{array}$ & $\begin{array}{r}7.96 \\
7.70 \\
14.92 \\
8.63 \\
5.71 \\
10.02\end{array}$ & $\begin{array}{l}1.02 \\
2.69 \\
0.99 \\
0.94 \\
0.75 \\
0.71\end{array}$ & $\begin{array}{l}0.4 \\
0.02 * \\
0.3 \\
0.4 \\
0.5 \\
0.2\end{array}$ & $\begin{array}{l}28 \\
11 \\
11 \\
13 \\
13 \\
14\end{array}$ & $\begin{array}{l}-6.56 \\
=19 \cdot 13 \\
-13.21 \\
=6.51 \\
=2.71 \\
-5.60\end{array}$ & $\begin{array}{l}4 \cdot 36 \\
5 \cdot 43 \\
6 \cdot 71 \\
5 \cdot 39 \\
4 \cdot 38 \\
4 \cdot 81\end{array}$ & $\begin{array}{l}1.50 \\
3.52 \\
1.97 \\
1.19 \\
0.61 \\
1.36\end{array}$ & $\begin{array}{l}0 \cdot 2 \\
0.01^{*} \\
0 \cdot 1 \\
0 \cdot 3 \\
0 \cdot 6 \\
0 \cdot 2\end{array}$ \\
\hline
\end{tabular}

* Statistically significant.

1.2. Neither for the patients as a whole nor for those with particular emotional symptoms was there a significant difference from the normal subjects (Table III).

In the control group the metabolic rate increases in nearly linear fashion from lying to sitting, and from sitting to standing, and the increment is statistically significant in both cases (Table IV). In the patients too a statistically significant difference is observed in metabolic rate as the subject changes from the lying to the sitting position; this holds true for the whole group and for the anxious patients, taken separately. The situation is different, however, for the change from sitting to standing; here the increment in energy expenditure for the patients taken as a whole does not reach statistical significance. When, however, the patients are divided into those with and those without manifest anxiety, it is the former who fail to step up the oxygen consumption when they stand, whereas those who are free from anxiety increase their energy expenditure just as the controls do (Table IV).

This finding is confirmed by direct comparison of patients and normal subjects in respect of increment or decrement after the change from sitting to standing (Table V). The anxious patients differ sig- nificantly from the normals, but this cannot be said of the entire group of patients or for any other group defined on the basis of symptoms observed. A similar result is obtained by comparing patients with the normal subjects of Booyens and McCance (1957), after converting their figures into percentages of Robertson and Reid (1952) expected mean.

Total ventilation, or respiratory volume, in the lying position is highest in controls and lowest in patients without anxiety (Table II). After both changes of posture, the patients without anxiety have the largest mean increment in respiratory volume. The means for respiratory rate (Table II) are very similar in the lying position, the anxious patients having higher values than the other patients or the normals.

When lying, the controls have the highest mean tidal air, followed by the anxious and then the nonanxious patients (Table II).

The oxygen content of the expired air shows interesting features (Table II). In the lying position it is almost identical in the anxious and the nonanxious patients, but is higher in them than in the controls. After sitting up, the oxygen content of the expired air increases in the controls and nonanxious patients, but it falls in the anxious patients. 
TABLE VI

MEAN DIFFERENCES IN OXYGEN CONCENTRATION OF EXPIRED AIR IN NORMAL CONTROLS ANXIOUS, AND NONANXIOUS PSYCHIATRIC PATIENTS AFTER CHANGE OF POSITION FROM LYING TO SITTING AND FROM SITTING TO STANDING

\begin{tabular}{|c|c|c|c|c|c|}
\hline Group & $\mathbf{n}$ & $\begin{array}{l}\text { Mean Differences in } \\
\text { Oxygen Concentration } \\
\text { of Expired Air }\end{array}$ & S.E. & $\mathbf{t}$ & $\mathbf{P}<$ \\
\hline $\begin{array}{l}\text { After Change of Position from Lying to Sitting } \\
\text { Normal controls } \\
\text { Anxious patients } \\
\text { Non-anxious patients }\end{array}$ & $\begin{array}{l}10 \\
11 \\
17\end{array}$ & $\begin{array}{r}0.138 \\
-0.091 \\
0.207\end{array}$ & $\begin{array}{l}0 \cdot 072 \\
0 \cdot 15 \\
0 \cdot 11\end{array}$ & $\begin{array}{l}1.91 \\
0.60 \\
1.88\end{array}$ & $\begin{array}{l}0 \cdot 1 \\
0 \cdot 6 \\
0 \cdot 1\end{array}$ \\
\hline $\begin{array}{l}\text { After Change of Position from Sitting to Standing } \\
\text { Normal controls } \\
\text { Anxious patients } \\
\text { Non-anxious patients }\end{array}$ & $\begin{array}{l}10 \\
11 \\
17\end{array}$ & $\begin{array}{l}0.095 \\
0.511 \\
0.097\end{array}$ & $\begin{array}{l}0.11 \\
0.22 \\
0.15\end{array}$ & $\begin{array}{l}0.88 \\
2.32 \\
0.64\end{array}$ & $\begin{array}{l}0.5 \\
0.05 * \\
0.6\end{array}$ \\
\hline
\end{tabular}

*Statistically significant.

TABLE VII

BASAL SKIN RESISTANCE OF PSYCHIATRIC PATIENTS, IN LYING POSITION COMPARED WITH THAT OF NORMAL CONTROLS $(\mathrm{n}=10)$

\begin{tabular}{|c|c|c|c|c|c|}
\hline Group & $\mathbf{n}$ & $\begin{array}{l}\text { Mean Difference in } \\
\text { Basal Skin Resistance } \\
\text { between Patients and } \\
\text { Controls (Lying) }\end{array}$ & S.E. & $t$ & $\mathbf{P}$ \\
\hline $\begin{array}{l}\text { All Patients } \\
\text { More disturbed } \\
\text { Less disturbed } \\
\text { Anxious } \\
\text { Non-anxious }\end{array}$ & $\begin{array}{l}28 \\
15 \\
12 \\
12 \\
15\end{array}$ & $\begin{array}{l}-0.569 \\
-0.668 \\
-0.530 \\
-0.730 \\
-0.480\end{array}$ & $\begin{array}{l}0 \cdot 20 \\
0 \cdot 20 \\
0 \cdot 20 \\
0 \cdot 24 \\
0 \cdot 19\end{array}$ & $\begin{array}{l}2 \cdot 98 \\
3 \cdot 22 \\
2 \cdot 65 \\
3.04 \\
2 \cdot 52\end{array}$ & $\begin{array}{l}0.01^{*} \\
0.01^{*} \\
0.02^{*} \\
0.01^{*} \\
0.02^{*}\end{array}$ \\
\hline
\end{tabular}

* Statistically significant.

Finally in the standing position the oxygen content of the expired air rises markedly in anxious patients and distinguishes them from controls and nonanxious patients (Table VI).

For the anxious patients, the $\mathrm{CO}_{2}$ content of the expired air is practically identical in lying and sitting, but there is a marked fall on standing up. In the non-anxious patients and the control subjects, the fall in $\mathrm{CO}_{2}$ content of the expired air is gradual and similar in the two groups after each change of posture (Table II).

The respiratory quotient (Table II) in all three positions is highest for the anxious patients, lowest for the normal subjects; the non-anxious patients occupy an intermediate position.

The increments in pulse rate observed after each change of position are not significantly different in the three groups (Table II).

Basal Skin Resistance.-The individual readings of B.S.R. converted into $\log$ resistance scores to reduce scatter and facilitates statistical treatment, are shown in Table I. The mean score of patients is below that of the control group and Table VI shows that this difference is significant.

\section{Discussion}

Analysis of the differences in metabolic rate increment from position to position shows that all groups significantly increase their energy expendi- ture in sitting. Control and non-anxious subjects show a further increase in the standing position, but they are not followed in this by the patients with marked anxiety. In fact, the metabolic rate of nine out of 11 anxious subjects when standing was lower than in the preceding sitting position. The term "anxiety" is used here, as previously, to designate an anticipatory feeling state of unpleasant or distressing quality.

The explanation of this finding might be sought in a disorder of respiratory regulation leading to inefficient function through increased respiratory rate, diminished tidal air, and larger respiratory dead space, as demonstrated for the effort tolerance of soldiers suffering from neurocirculatory asthenia (Haldane, Meakins, and Priestley, 1919; Cohen and White, 1947).

Our results show that respiratory regulation, for total ventilation, respiratory rate, and tidal air follows the same pattern in psychiatric patients, whether anxious or not, as in normal control subjects. The low oxygen uptake of anxious patients on standing up cannot therefore be explained by a disorder of respiratory regulation.

In healthy subjects and non-anxious patients the adaptation to postural change is characterized by a small $(2.7$ to $5.4 \%)$ decrease in oxygen extraction, more than compensated in both groups by the concomitant rise in minute respiratory volume which is therefore primarily responsible for the metabolic 


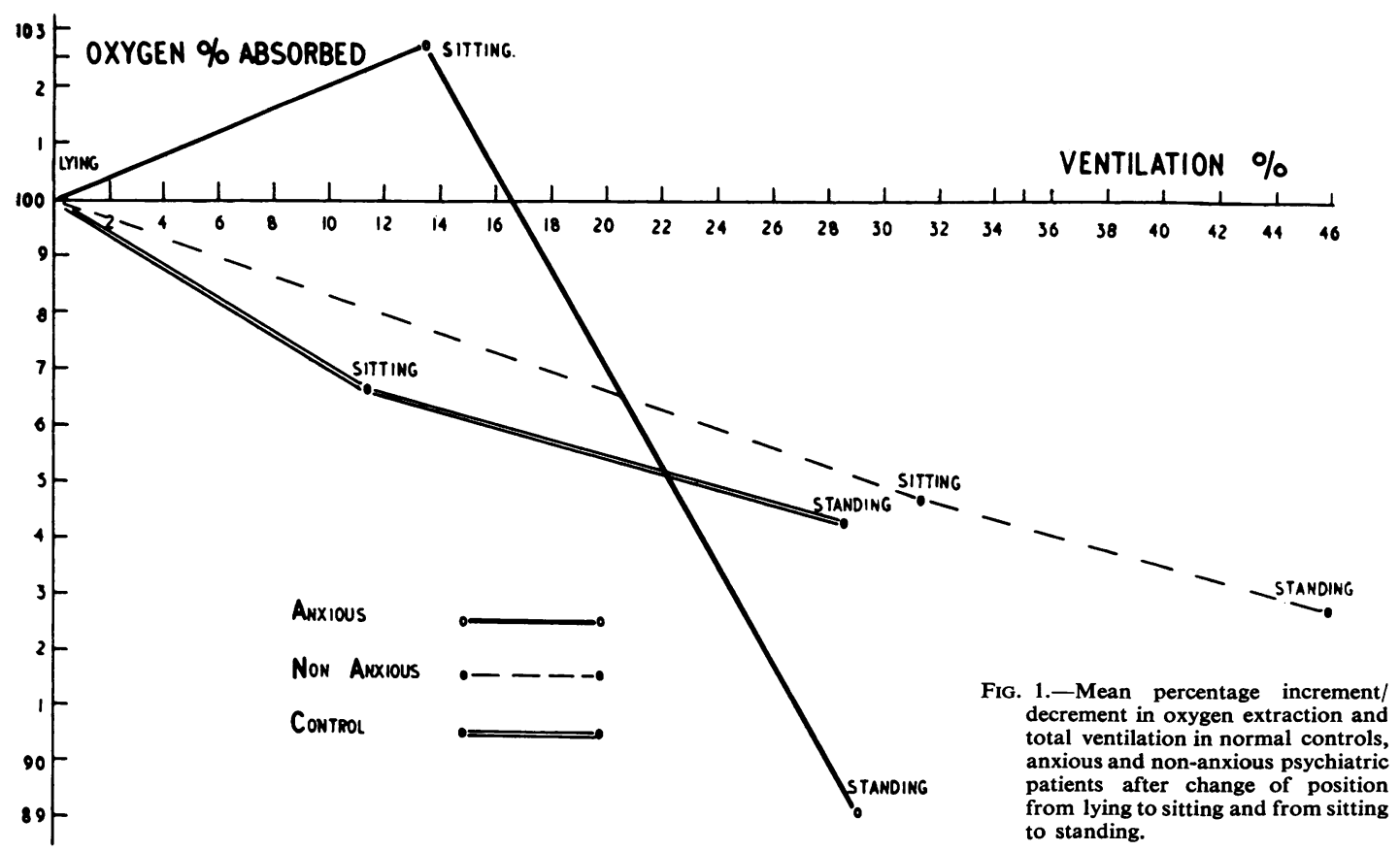

readjustment. This is in accordance with Durnin and Edwards' (1955) observation that, within the moderate ventilatory range, energy expenditure can be predicted from minute respiratory volume alone, with only a small margin of error.

In anxious patients the metabolic adaptation in response to postural change appears to be determined by the rate of oxygen extraction from the inspired air, which follows a different pattern from that observed in the two other groups (Fig. 1). On sitting up, oxygen extraction is increased to $102.3 \%$ of the lying value, and the metabolic rate rises. On standing up there is a reversal of the trend in oxygen extraction which falls by $13 \cdot 1 \%$, a significant amount; the increment in ventilation is not sufficient to compensate for the low oxygen yield and there can be no rise in energy expenditure (Table VI).

The measurements of electrical skin resistance confirm the psychological rating and allow clear-cut differentiation of controls and patients, the latter having a significantly lower skin resistance. Both anxious and non-anxious patients have a low mean B.S.R. This is in accordance with the fact (White, 1930; Freeman and Simpson, 1938) that palmar sweating is not the only factor that reduces electrical resistance of the skin, and generalized muscular contraction or tension have a similar, though possibly less marked, effect. Our findings also confirm the results of Freeman and Giffin (1939) regarding the tendency to an inverse relationship between metabolic rate and basal skin resistance in the lying position.

This experiment does not allow a definite answer to the question whether the anxiety discussed here differs only in its quantity, or also qualitatively, from that observable in normal people. We are inclined to the view that there is only a quantitative difference as the lower metabolic rate in standing although occurring much more frequently in the very anxious patients, was certainly not confined to them; it was observed not only in several of our patients without severe anxiety, but also in one of our normal subjects (Subject 3) and in five of the series of Booyens and McCance (Melville and Mezey, 1959).

The explanation of these findings can only be speculative at present. Increased work unaccompanied by a rise in oxygen consumption presupposes either greater efficiency, or accumulation of oxygen deficit, and deteriorating performance through fatigue. Of the former, there was no other evidence, but greater efficiency of anxious patients cannot be ruled out on $a$ priori grounds: an emotionally induced increase of adrenocortical activity might have been present in these subjects, and it has been shown in animal experiments (Ingle, Morley, and Nezamis, 1952) that a considerable improvement of work performance accompanies the continuous administration of cortisone. The failure of the 
anxious subjects to increase energy expenditure when changing from sitting to standing could not be attributed to reduced function because the effect was too rapid for any action mediated by the thyroid gland and the level of serum protein-bound iodine was always within normal limits.

Excess adrenaline or noradrenaline secretion in the anxious group of patients has also been considered. Allen, Barcroft, and Edholm (1946) showed that after initial vasodilatation adrenaline produces a secondary vasoconstriction in the human skeletal muscle; diminished blood flow in this secondary phase could make the muscular system unable to increase its oxygen uptake according to tissue demand. However, the anxiety discussed here was not a transient phenomenon provoked for the purposes of the experiment but was prolonged, and the vasoconstriction reported by Allen et al. was only relative, the blood flow remaining well above the initial resting state.

The findings reported here would be more in keeping with the action of noradrenaline which tends to reduce muscular blood flow (Goldenberg, Aranow, Smith, and Faber, 1950); the effect of noradrenaline on respiration (Whelan and Young, 1953) is consistent with our findings in the anxious group of subjects. Euler, Luft, and Sundin (1955) have shown that, after changing from recumbency to standing, there is a considerable increase in the excretion of noradrenaline; they regarded it as induced by stimulation of the vasomotor nerves that followed the orthostatic fall in the blood pressure. Finally, Elmadjian, Hope, and Lamson (1957) have demonstrated increased noradrenaline excretion in anticipatory states. Whether excess noradrenaline secretion or some other factor is responsible, the observed abnormal oxygen extraction is probably dependent on circulatory changes (Sharpey-Schafer, Hayter, and Barlow, 1958) interfering with the alveolar absorption of oxygen, its transport, or its consumption in the skeletal muscles.

\section{Summary}

Metabolic and respiratory adaptation in the consecutive lying, sitting, and standing positions was studied in a group of 32 psychiatric patients and 10 healthy subjects.

There was no significant difference between normals and patients in their mean energy expenditure in lying. Control subjects and non-anxious patients showed a linear increase in their metabolic rate, with a significant rise after each change of position; anxious patients had a significant increment when sitting up, but failed to show any further increase on standing. The difference between controls and anxious patients (in their metabolic rate increment after changing from sitting to standing) is statistically significant.

The normal subjects, the anxious patients, and the non-anxious patients do not differ among themselves in respect of minute respiratory volume, respiratory rate, and tidal air in the three body postures.

The oxygen extraction of normal subjects and non-anxious patients is similar, and a small decrease is observed after each change of posture. The anxious patients differ from both these groups in that their oxygen extraction increases slightly after the first change and falls considerably on standing up.

The differential pattern of oxygen extraction in anxious patients is shown to be responsible for the failure of their metabolic rate to rise when they stand up.

Measures of basal skin resistance were concordant with the psychological rating of the emotional state and allowed differentiation of normal subjects from anxious and non-anxious patients.

The significance of these findings and the underlying physiological mechanisms are discussed.

We wish to thank Dr. A. E. Maxwell for generous help with the statistical treatment, Dr. C. Rashbass for many helpful suggestions, Dr. P. H. Venables for advice $\Omega$ on the measurements of electrical skin resistance, Dr. O. G. Edholm and Mr. H. S. Wolff (Division of $\vec{\theta}$ Human Physiology, Medical Research Council, Hamp 윽 응 stead) for suggestions and criticisms, Mrs. T. A. Maxwell for secretarial and Mrs. V. A. Oniwinde for technical assistance.

This work was carried out with the help of the Ford Foundation.

\section{REFERENCES}

Allen, W. J., Barcroft, H., and Edholm, O. C. (1946). J. Physiol. (Lond.), $105,255$.

Altschule, M. D. (1953). Bodily Physiology in Mental and Emotional Disorders. Grüne \& Stratton, New York.

Bartels, E. C. (1949). J. clin. Endocr., 9, 1190.

Bartels, E. C. (1949). J. clin. Endocr., 9, 1190.

Booyens, J., and McCance, R. A. (1957). Lancet, 1, 225.
Bornstein, A. (1908). Mschr. Psychiat., Neurol., 24, 392.

Bornstein, A. (1908). Mschr. Psychiat., Neurol., 24, 392.
Clausen, J. (1951). Acta psychiat. (Kbh.) Neurol. Suppl. 68.

Cohen, M. E., Johnson, R. E., Consolazio, F., and White, P. D. (1946). J. clin. Invest., 25, 920.

- - and White, P. D. (1947). Ibid., 26, 520.

Crile, G. W. (1922). Arch. Surg., (Chicago), 4, 130.

Deutsch, F. (1925). Wien. klin. Wschr., 38, 1127.

Dunbar, F. (1954). Emotions and Bodily Changes, 4th ed. Columbia University Press, New York.

Durnin, J. V. G., and Edwards, R. G. (1955). Quart. J. exp. Physiol., 40, 370.

Elmadjian, F., Hope, J. M., and Lamson, E. T. (1957). J. clin. Endocr., 17, 608.

Euler, U. S. von, Luft, R., and Sundin, T. (1955). Acta physiol. scand. 34, 169.

Finesinger, J. E. (1939). Arch. Neurol. Psychiat. (Chicago), 42, 425.

Freeman, G. L., and Giffin, L. L. (1939). J. gen. Psychol., 21, 63.

Freeman, G. L., and R. M. (1938). Ibid., 18, 319.

Goldenberg, M., Aranow, H., Smith, A. A., and Faber, M. (1950) Arch. intern. Med., 86, 823 .

Greving, H. (1935). Arch. Psychiat. Nervenkr., 104, 163.

Greving, (1941). Ibid., 112, 613 . 
Haldane, J. S., Meakins, J. C., and Priestley, J. G. (1919). J. Physiol. (Lond.), 52, 433.

Hoskins, R. G. (1941). Endocrinology, Norton, New York. Ingle, D. J., Morley, E. H., and Nezamis, J. E. (1952). Endocrinology, 51, 487

Jones, M., and Scarisbrick, R. (1946). Psychosom. Med., 8, 188.

Melville, P. H., and Mezey, A. G. (1959). Lancet, 1, 273.

Müller, E. A. (1950). Arbeitsphysiologie, 14, 271.

Robertson, J. D., and Reid, D. D. (1952). Lancet, 1, 940.

Scholander, P. F. (1947), J, biol Chem., 167, 235.

Schou, H. I. (1937). Acta psychiat. scand. Suppl. 14.
Segal, H. L., Binswanger, H. F., and Strouse, S. (1928). Arch. intern. Med., 41, 834

Sharpey-Schafer, E. P., Hayter, C. J., and Barlow, E. D. (1958). Brit. med. J., 2, 878

Venables, P. H. (1955). Quart. J. exp. Psychol., 7, 12.

Whelan, R. F., and Young, L. M. (1953). Brit. J. Pharmacol., 8, 98.

White, M. M. (1930). J. exp. Psychol., 13, 267.

Wolf, H. S. (1958). Quart. J. exp. Physiol., 43, 270.

Wuth, O. (1928). In Bumke's Handbuch der Geisteskrankheiten, Vol. III, Pt 3., ed. O. Bumke. Springer, Berlin. 